See Article page XXX.

\section{Commentary: What's a girl like you doing with a heart like this?}

\author{
Stephanie N. Nguyen, MD, ${ }^{\mathrm{a}, \mathrm{b}}$ David Blitzer, MD, ${ }^{\mathrm{a}, \mathrm{b}}$ \\ Jennifer Haythe, MD, ${ }^{a, c}$ \\ Yuichi J. Shimada, MD, MPH, ${ }^{\text {a,c }}$ \\ Shepard D. Weiner, MD, ${ }^{\mathrm{a}, \mathrm{c}}$ and \\ Hiroo Takayama, MD, $\mathrm{PhD}^{\mathrm{a}, \mathrm{b}}$
}

Osman and colleagues investigate sex differences in shortterm outcomes after septal myectomy (SM) for obstructive hypertrophic cardiomyopathy (HCM). ${ }^{1}$ The US National Readmission Database was queried to identify a total of 3031 patients who underwent SM for HCM between 2015 and 2018. The authors found that female patients had a higher rate of postoperative pacemaker requirement, more nonhome discharges, longer hospital length of stay, and higher 30-day readmission compared with men. This study reinforces the known gender differences in clinical manifestations and outcomes across a wide array of cardiovascular diseases $^{2}$ and adds to the growing interest in sex-specific disparities in HCM in the contemporary literature.

Hypertrophic cardiomyopathy is an autosomal dominant disease and thus its presence in the general population is expected to be equal between genders. However, prior studies have noted HCM to be a male-predominant condition, demonstrating a male majority ranging from $55 \%$ to $78 \%{ }^{3}$ Women with HCM are often underdiagnosed, thus tend to present at an older age with more advanced symptoms than men. ${ }^{3-10}$ The present study highlights sex

\footnotetext{
From the ${ }^{\mathrm{a}}$ Hypertrophic Cardiomyopathy Center, ${ }^{\mathrm{b}}$ Division of Cardiac, Thoracic, and Vascular Surgery, Department of Surgery, and ${ }^{\mathrm{c}}$ Division of Cardiology, Department of Medicine, Columbia University Medical Center/NewYork-Presbyterian, New York, NY

Disclosures: The authors reported no conflicts of interest.

The Journal policy requires editors and reviewers to disclose conflicts of interest and to decline handling or reviewing manuscripts for which they may have a conflict of interest. The editors and reviewers of this article have no conflicts of interest.

Received for publication Dec 3, 2021; revisions received Dec 3, 2021; accepted for publication Dec 6, 2021.

Address for reprints: Hiroo Takayama, MD, PhD, Hypertrophic Cardiomyopathy Center and Division of Cardiac, Thoracic, and Vascular Surgery, Department of Surgery, Columbia University Medical Center, 177 Fort Washington Ave, New York, NY 10032 (E-mail: ht2225@cumc.columbia.edu).

J Thorac Cardiovasc Surg 2021; $\mathbf{\square}: 1-2$

$0022-5223 / \$ 36.00$

Copyright (C) 2021 by The American Association for Thoracic Surgery

https://doi.org/10.1016/j.jtcvs.2021.12.011
}

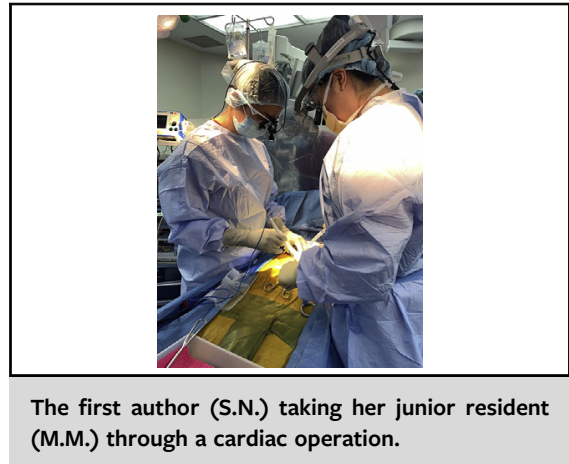

CENTRAL MESSAGE

Sex-specific management may enable earlier detection and improve postoperative outcomes for women with hypertrophic cardiomyopathy.

disparity in HCM, demonstrating a significantly more complicated postmyectomy course in female patients. Nonetheless, short- and long-term survival following SM is reassuringly equivalent across genders. ${ }^{1,6}$

These findings from the clinical and administrative datasets provide us with food for thought regarding the underlying mechanisms of sex differences in HCM. Among numerous biological differences between men and women, which account for pre- and perioperative characteristics, it is important to consider a discrepancy in heart size between male and female patients. Firstly, women generally have a thinner septum at baseline; thus, by the time diagnostic criterion of septal wall thickness $\geq 15 \mathrm{~mm}$ is reached, a woman's heart may have undergone greater relative hypertrophy, which accounts for a more advanced disease state at the time of diagnosis. ${ }^{7}$ Secondly, and more relevant to the readership, it may be more difficult to perform a comprehensive surgical myectomy of the septum in a smaller heart. Perhaps this explains why Osman and colleagues ${ }^{1}$ report a higher incidence of new pacemaker implantation following SM in women. In fact, a similar susceptibility to conduction disturbances in women following surgical aortic valve replacement has recently been reported. ${ }^{11}$ Given the established literature reporting worse outcomes in women following cardiac surgical procedures, ${ }^{12,13}$ one may hypothesize that smaller cardiac structures lead to worse outcomes in adult cardiac surgery. Thus, there may be an opportunity for 
surgeons to improve our skillset and influence outcomes, particularly for HCM.

Beyond sex analysis, the overall rates of in-hospital mortality and pacemaker requirement appear too high for contemporary SM for HCM. Of note, concomitant aortic and mitral valve replacement or coronary artery bypass grafting was performed far more frequently than expected. The study cohort may have consisted of patients with a mixed bag of diagnoses who had undergone SM, instead of those who truly had HCM. Let's hope that the concomitant procedures, particularly valve replacements, were not added on by inexperienced hands.

\section{References}

1. Osman M, Syed M, Osman K, Patel B, Kawsara A, Kheiri B, et al. Sex-based outcomes of surgical myectomy for hypertrophic cardiomyopathy: an analysis from the national readmission database. J Thorac Cardiovasc Surg. 2022. XX:XX-X.

2. EUGenMed Cardiovascular Clinical Study Group, Regitz-Zagrosek V, OerteltPrigione S, Prescott E, Franconi F, Gerdts E, et al. Gender in cardiovascular diseases: impact on clinical manifestations, management, and outcomes. Eur Heart J. 2016;3:24-34. https://doi.org/10.1093/eurheartj/ehv598

3. Olivotto I, Maron MS, Adabag AS, Casey SA, Vargiu D, Link MS, et al. Genderrelated differences in the clinical presentation and outcome of hypertrophic cardiomyopathy. J Am Coll Cardiol. 2005;46:480-7. https://doi.org/10.1016/j. jacc.2005.04.043

4. Huurman R, Schinkel AFL, de Jong PL, van Slegtenhorst MA, Hirsch A, Michels M. Impact of sex on timing and clinical outcome of septal myectomy for obstructive hypertrophic cardiomyopathy. Int J Cardiol. 2021;323:133-9. https://doi.org/10.1016/j.ijcard.2020.08.059
5. Rowin EJ, Maron MS, Wells S, Patel PP, Koethe BC, Maron BJ. Impact of sex on clinical course and survival in the contemporary treatment era for hypertrophic cardiomyopathy. J Am Heart Assoc. 2019;8:e012041. https://doi.org/10.1161/ JAHA.119.012041

6. Meghji Z, Nguyen A, Fatima B, Geske JB, Nishimura RA, Ommen SR, et al. Survival differences in women and men after septal myectomy for obstructive hypertrophic cardiomyopathy. JAMA Cardiol. 2019;4:237-45. https://doi.org/10.1001/ jamacardio.2019.0084

7. van Driel B, Nijenkamp L, Huurman R, Michels M, van der Velden J. Sex differences in hypertrophic cardiomyopathy: new insights. Curr Opin Cardiol. 2019; 34:254-9. https://doi.org/10.1097/HCO.0000000000000612

8. Nijenkamp LLAM, Bollen IAE, van Velzen HG, Regan JA, van Slegtenhorst M, Niessen HWM, et al. Sex differences at the time of myectomy in hypertrophic cardiomyopathy. Circ Heart Fail. 2018;11:e004133. https://doi.org/10.1161/ CIRCHEARTFAILURE.117.004133

9. Ghiselli L, Marchi A, Fumagalli C, Maurizi N, Oddo A, Pieri F. Sex-related differences in exercise performance and outcome of patients with hypertrophic cardiomyopathy. Eur J Prev Cardiol. 2020;27:1821-31. https://doi.org/10.1177/ 2047487319886961

10. Huang F, Shah JP, Pu X, Hagar A, Chen S. Influence of gender on clinical characteristics and outcomes in Chinese patients with hypertrophic cardiomyopathy. Am J Med Sci. 2020;360:517-24.

11. Dalén M, Persson M, Glaser N, Sartipy U. Sex and permanent pacemaker implantation after surgical aortic valve replacement. Ann Thorac Surg. October 11, 2020 [Epub ahead of print]. https://doi.org/10.1016/j.athoracsur.2021.09. 009

12. Edwards FH, Carey JS, Grover FL, Bero JW, Hartz RS. Impact of gender on coronary bypass operative mortality. Ann Thorac Surg. 1998;66:125-31. https: //doi.org/10.1016/s0003-4975(98)00358-0

13. Blankstein R, Ward RP, Arnsdorf M, Jones B, Lou YB, Pine M. Female gender is an independent predictor of operative mortality after coronary artery bypass graft surgery: contemporary analysis of 31 Midwestern hospitals. Circulation. 2005;112(9 Suppl):I323-7. https://doi.org/10.1161/CIRCULATIONAHA.104.5 25139 